\title{
Becoming a wage earned or a self-employed: Does Young Educational Level determine the Choice of the Working Labour Force Status in Cameroon?
}

KOUL NGWE MANGUELLE Maximilien ( $\nabla$ m_manguelle@yahoo.fr ) Université de yaoundé 2 https://orcid.org/0000-0002-2997-7830

\section{Research Article}

Keywords: Employment, human capital, educational level, young people, wage earned, self-employed Posted Date: October 5th, 2021

DOl: https://doi.org/10.21203/rs.3.rs-955868/v1

License: (c) (1) This work is licensed under a Creative Commons Attribution 4.0 International License. Read Full License 


\section{Abstract}

If employment is recognized as a key driver for growth, development and well-being improvement, human capital is probably a main determinant of the labour force participation. By often analyzing this relationship in wage earning jobs, studies used to leave self-employment untreated despite the fact that its proportion is growing significantly in several countries. This leads us to the following question: does human capital accumulated determine access to all forms of employment? Focusing on young people, this article analyzes effects of educational level used as a proxy of the human capital accumulated on the choice of the working labour force status in Cameroon. Using discrete-choice models on data draw from the second Employment and Informal Sector Survey carried out by the National Institute of Statistics, empirical findings reveal that educated young people are more disposed to make a decision to work as wage earned and the corresponding probability rises with the increasing of their educational levels. However, their willingness to become self-employed decline with the rising of their educational levels. Therefore, compared to the decision to work as a wage earned, becoming a self-employed does not appear as a human capital outcome. This paradoxical result for a low wage economy suggests a reform of the educational or training system starting at least in high school level with emphasizes in sectors with a high potential of self-employment and a setting-up of an apprenticeship plan.

\section{Introduction}

In most countries, human capital is considered as a key factor which conditions the labour force participation. Due to that, educational policies and labour markets continuously evolve in several countries. So, before the mid-1980s crisis, most Sub-Saharan African (SSA) states as main employers led educational policies focused on training for wage earning jobs. But, this model where less educated persons were often enrolled on a dynamic agricultural sector, showed its limits with the crisis. To face crisis, numerous states adopted Structural Adjustment Programs which implementations affected their labour market functioning. Consequently, from 1988 to 1994, privatizations, company closures and recruitment restrictions had been observed in many SSA countries. According to the National Institute of Statistics (NIS, 2005), Cameroon registered during this period the disappearance of 1,040 companies with 29,012 jobs loosed and 76,187 redundancies due to staff reductions in 1,193 companies. Country also faced a deterioration of labour market performance indicators such as a rising in unemployment rate from 5.6 to 8.1 per cent and a falling in wage rate from 17.9 to 15.3 per cent between 1991 and 1996 (World Bank, 2019).

In response to this situation, government laid out reforms between 1990 and 2000 which some led to the promotion of the labour market flexibility (See Law n ${ }^{\circ}$ 22/007 of August 14, 1992 relating to the Cameroon Labour Code). Following the Millennium Development Goals (MDGs), it added to the poverty reduction strategy, a strategy to reform the National Employment Policy (NEP) based on self-employment promotions. From this perspective, many employment programs had been initiated to help disadvantaged groups (women, young and disabled) and a disseminating information policy had been developed to facilitate job search procedures and reduce barriers to mobility in the labour market ${ }^{1}$. In addition, 
educational and training systems had been reformed in order to ensure a better matching between labour force and labour market requirements (See Order n01/0096 MINSUP of December 7, 2001 relating to the setting up and functioning conditions of Private Higher Educational Institutes).

Despite the improvement of the labour market functioning derived from these reforms (a rising in wage rate from 15.3 per cent to 22.4 per cent and a falling in unemployment rate from 8.1 per cent to 4.3 per cent between 1996 and 2014), their effects on decent job access are contrasted by several major facts. Adding to the rising of the first-time job seeker rate (46.7 per cent in 2005 vs 53.1 per cent in 2010), the overall underemployment rate ( 75.8 per cent, 70.6 per cent and 77 per cent in 2005, 2010 and 2014), still higher compared to the setting target of under 50 per cent in 2020 stated in the Growth and Employment Strategy Document (National Institute of Statistics, 2015).

A similar assessment had been observed in the poverty rate which the setting target was less than 28.7 per cent (40.1 per cent, 39.9 per cent and 37.5 per cent respectively in 2001, 2007 and 2014), and in the informality rate (close to 90 per cent since 2005). These difficulties are amplified among young people, who represent more than 33 per cent of the population and have underemployment and extended unemployment rates estimated respectively at 71.4 per cent and 15.5 per cent in 2010 . Adding to the unemployment, which increases with the level of education, young persons who already left school are closed to 70 per cent and most are first-time job seekers (77.1 per cent in rural area and 64.5 per cent in urban area) (National Institute of Statistics, 2014 and 2015).

Stylized facts above outline the relevance to question the effect of the educational level on the choice of the working labour force status particularly on this period of COVID 19 pandemic. Our analysis focus on young persons and on the decision to choose to work as a wage earned or as a self-employed in order to take in consideration the segmentation of the labour market which is often observed in comparable SSA countries.

The remainder of the paper is organized as follows. Section 2 sets out a brief literature review. Section 3 and 4 respectively describe methodological approach and data. Section 5 discusses our empirical findings and finally, Section 6 provides some concluding comments.

[1] Employment promotion programs such as Integrated Support Program for Informal Sector Actors (PIAASI), National Action Plan for Youth Employment (PANEJ) and Support Program for Rural and Urban Youth (PAJER-U) had been set up and structures as National Employment Fund, University and Professional School Guidance Council, Labour Force Office, etc., had been created by the government of Cameroon.

\section{Human Capital Accumulation And Youth Labour Force Participation: A Brief Literature Review}

Using the educational level as a proxy of the human capital accumulated, this section briefly reviews theoretical and empirical studies ran to analyze how young educational levels affect their labour force 
participation.

\subsection{Educational level: a fundamental asset for youth labour force participation}

Effects of education on labour market participation are usually analyzed with the human capital theory (Becker, 1964) which assumes that differentiations on individual productivities provide from their human capital investments intended to be valorized in the labour market by attempting good jobs (i.e. jobs with high wages and best working conditions) in the future. For that purpose, this theory offers a coherent vision of educational or training pathways as a set of rational decisions individuals made in order to improve their productivities, which should allow a successful insertion in the labour market. This supposes that persons with high levels of education have more chances to find good jobs. Following these hypothesis, Vincens (1998) argued that labour market insertion begins at school and it is strongly influenced by the educational or training choice. From this perspective, young people with low levels of education often faced difficulties to enter labour markets because their productive capacities are judged insufficient due to the weakness of their general education and their lack of experience.

Consequently, educated young people have better chances to get out of unemployment due to the human capital accumulated (Giret, 2000; Vincens, 1999a and 1999b). Germe and Marsden (1991) analyzed the relationship between education and job access in France and found that training system characteristics play a relevant role on youth labour market insertion. In the same vein, Martinelli et al. (1999) established that five years after leaving the educational or training system, young people who were well-educated had better situations in French labour market. In Brazil, Telles (1993) found that formal education is a fundamental criterion to the insertion in the formal sector. Author argued that educated young people are less exposed to unemployment and have in average more chances to find good jobs. A study conducted by the Organization for Economic Cooperation and Development (OECD, 1996) on six countries (United Kingdom, France, Germany, Sweden, Spain and Italy) established that, if the training system plays a relevant role on youth insertion pathways, its effect could differ from country to country. For that purpose, this study revealed that youth unemployment rate is low in Germany where professional training takes place in companies during the schooling pathway and high in Sweden where it takes place at school.

Several studies in African showed that the lack of human capital amplifies the vulnerability of young people in the labour market. Consequently, less educated ones are often trapped in underemployment due to the insufficient of their accumulated human capital (Word Bank, 2009; Antoine et al., 2001). Following this view, Diagne (2006) found that, those with high level of education usually experimented short periods of unemployment in Senegal. In Ivory Coast, Carmoe (2006) found that, youth labour market access is strongly correlated to the training or educational system and to the educational level, which appear as main determinants of labour market access. Based on the working-age population, Totouom et al. (2018) established a positive relationship between formal education and job access in the formal sector in Cameroon. 
Henceforth, if numerous studies support that the human capital acquired in the educational or training system is a key determinant of the labour market access procedure, others also highlight the relevant effect of non-formal training (Vernières, 1997; Drancourt and Roulleau-Berger, 1996). Taking this aspect in account with the distinction between general and specific training, Becker (1964) argued that specific training also affect the individual productivity and the labour market access. In the same vein, Bowles and Gintis (1976) supported that non-cognitive knowledges had a positive effect on productivity and professional careers. Authors concluded that developing these knowledges or skills during the schooling pathway could facilitate youth labour market insertion. Indeed, the dual educational training system implemented in Germany showed that combining school training with company and apprenticeship training improved the insertion of young people because they are closed to labour market realities (Lattard, 1995; Weibhuhn and Buchel, 1994). Using American data, Carnoy and Levin (1985) found that young people with good social capital and high level of human capital easily access to employment. In France, Bonnal et al. (1995) found that, internships and insertion schemes have positive effects on the job search process. Lemelin (1998) obtained a similar result in Quebec and established that, these training courses are more effective when they are based on a solid foundation acquired in formal school.

\subsection{Educational level: an asset with limited effects on youth labour force participation}

The human capital theory (Becker, 1964) $)^{2}$ presents educational and training pathways as a set of rational decisions made in order to improve the productivity and facilitate the labour market insertion. Following this issue, there is a direct and positive relationship between the accumulated human capital materialized by the level of education or diploma and labour market access when we consider a competitive view of training and labour markets. This assumes that labour market functioning risk and uncertainty don't affect human capital investments. Consequently, compared to young people with high levels of education who are supposed to have more chances to get out of unemployment, those with low ones use to face difficulties to enter labour market due to the weakness of their training and their lack of experience. But, if several studies support this view, some question its scope because the human capital individuals accumulated provides from investments based on a cost-benefit trade-off.

According to Figure 1 above, it appears that human capital investments depend on people's beliefs about labour market returns in the future. Authors as Schultz (1961) and Becker (1964) early emphasized the necessity to take in account risk and uncertainty when analyzing the decision to invest in training or in education. In the same view, Weiss (1972) argued that decisions to invest in human capital are generally made in situation of uncertainty concerning future opportunities and expected returns. Author established that choices to continue to study are made at ages where young persons are often poorly informed about job opportunities and this limits their educational outcome knowledges. Others authors as Fang (1993), Fondeur and Minni (2006) supported that, including the labour market functioning risk is more relevant to understand young people choices in a situation of growing uncertainty about their professional future. For that purpose, Giret (2000) argued that youth insertion difficulties could derive from uncertainty about returns of educational investments especially for those who are academic graduated. By underlining the 
fact that the unemployment level affects opportunity costs associated to the decision to invest in human capital and influences educational and training choices and their duration, Kodde (1985) and Pissarides (1992) established a positive relationship between demand for education and unemployment.

Taking in account the difficulty to find a general consensus about effects of an anticipated unemployment rising on the training choice, Groot and Oosterbeek (1992) argued that uncertainty evaluated as the probability to be unemployed in the future affects human capital investment returns. Using American and Dutch data, these authors concluded that omitting this influence on earnings tended to depreciate educational returns. So, if young people extended their study durations in order to ensure better labour market insertion in the future, uncertainty could increase the demand of education and this could unfortunately, leads to an over professionalization and to a rising of the graduated unemployed rate. Lutzt (1991) and Drexel (1993) established in Germany, that an oversupply of training or education reduces young people's career progression and their access to managerial positions.

The saturation in the labour market entry which occurs due to the fact that young people became better trained than the labour market requirements often leads to a mismatch between training and employment. From this perspective, Tessaring (1993) argued that adding to the reduction of insertion chance and job promotion, a long schooling pathway also reduces the length of youth professional careers. In Germany, Mayer and Konietzka (1998) found that, generations or cohorts who faced difficulties to find jobs after graduation are forced to accept fixed-term and non-conventional jobs or jobs unsuited to their training. So, the job scarceness that leads to the deterioration of professional opportunities pulled out the study durations and intensified competition among graduated from the same training in the labour market.

A study focused on an analysis of young people insertion in Dakar revealed that despite the increasing in their educational levels, some had difficulties to keep their jobs and others to find jobs at the end of their study pathways (Diagne, 2006; Bocquier, 1995). In the same vein, Antoine et al. (2001) established that education has a low return among young people with high levels of education in Antananarivo, Dakar and Yaoundé. In Pointe-Noire and Brazzaville, Kuepié and Nordman (2013) found that youth unemployment increased among academic graduated and concluded that investing in education or in training did not necessarily lead to employment. Focusing on the labour force, Ekamena et al. (2014) and Totouom et al. (2018) obtained a negative relationship between education and labour market access in Cameroon and noted that educational returns could change with the level of education.

Using Cereq's data draw from the "Generation 92" survey, Meron and Minni (1995) found an increasing of unemployment rate disparities by level of education particularly among young people with high academic graduations between 1991 and 1996 in France. The observation of employment rates showed that, 41 per cent of young people who completed initial training in 1995 found jobs in 1996, compared to 50 per cent of those who left the educational or training system in 1990 and that, 2 over 5 young people were unemployed in 1995 compared to 1 over 5 in 1991. With the same data, Sollogoub and Ulrich (1998) observed a falling of the advantage for educated young people during their insertion process. The OECD 
study (1996) mentioned above stated that in United Kingdom and France, the educational level did not always guarantee a better insertion to young people. It concluded that educational or training system could sometimes fail to satisfy labour market requirements.

This brief literature review suggests that education has contrasted effects on youth insertion process. So, if the human capital accumulated appears as a fundamental asset for youth labour market access, it is relevant to underline that its effect is limited due to the uncertainty and risk relating to the labour market functioning.

[2] As labour market theories, see also the signal theory (Spence, 1974), job search and job matching theories (Lancaster, 1990; Mortensen, 1986; Miller, 1984; Lippman and McCall, 1974), institutional labour market theories (Lindeck and Snower, 1986; Piore, 1978; Doeringer and Piore, 1971)...

\section{Methodological Approach}

If some persons enter the labour force without passing by an educational or a training system, theoretical and empirical evidences based mainly on human capital theory (Becker, 1964) assume that individuals generally seek jobs or choose to participate to the working labour force in order to valorize the human capital accumulated from the educational or training pathway. According to this end, individual may made a decision to work based on how satisfying the job could be. Taking this in consideration, the dependent variable is constructed under the hypothesis of the canonical model of labour market participation ${ }^{3}$ which distinguishes: participants (i.e. labour force namely employed and unemployed) and non-participants (i.e. inactive).

To examine effects of young educational level on the choice of the working labour force status, we firstly release the hypothesis of the labour market uniqueness and assume that the working status included wage earned and self-employed ${ }^{4}$ which are considered as substitutes. These specifications lead us to consider these working status as occupational choices. We also assume that any individual has an initial level of human capital which equalizes the probability associated to these both decisions to work. From this perspective and according to the human capital theory (Becker, 1964), these occupational choices are considered as human capital outcomes. Following these assumptions discrete-choice models are adapted for estimations (Wooldridge, 2010; Long and Freese, 2001). If the Hausman and McFadden's (1984) test for the independence of irrelevant alternatives (IIA) is useful to verify if modalities of the dependent variable are independent when running a Multinomial Logit Model (MLM) or a Multinomial Probit Model (MPM), it does not guarantee the robustness of results obtained after regression. Taking this aspect in consideration, we will run a binary dependent variable model for each working status.

Let consider $j$ a working status observed (wage earned or self-employed) on the labour market representing the human capital outcome. $Y_{j}$ is defined as a response function to a set of unobserved latent variables $Y_{j}^{*}$ which measure the odds to choose the status $j$. Because this study focuses on 
decisions to work as wage earned and self-employed, we estimate a Standard Probit Model (SPM) where the dependent variable is defined as follow:

$$
Y_{j}=\left\{\begin{array}{c}
\text { 1ifindividualchoosesthestatusj } \\
\text { and } \\
\text { 0Otherwise }
\end{array}\right.
$$

Assuming that, for each individual $i$, the willingness to choose the working status $j$ is a linear function of observed characteristics, $Y_{i j}$ is related to $Y_{i j}^{*}$ by the following relationship:

$$
Y_{i j}=\left\{\begin{array}{c}
1 i f Y_{i j}^{*}>Y_{i k}^{*} \text { whithk } \neq j \\
\text { 0Otherwise }
\end{array}\right.
$$

$Y_{i j}^{*}$ is non observable and it is also a linear function defined as follows:

$$
Y_{i j}^{*}=\beta_{j} X_{i}+\epsilon_{i j}(3)
$$

In this equation, $X_{i}$ is a vector of individual characteristics (including the variable of interest: the educational level (EL) used as a proxy of human capital accumulated), $\beta_{j}$ is a vector of parameters to be estimated and $\epsilon_{i j}$ is the random error term. So, the odds for an individual $i$ to choose the status $Y_{j}$ matches with the propensity that the response function associated to $Y_{j}$ is greater than the one associated to other alternative and it is defined as follow:

$$
\operatorname{Prob}\left(Y_{i j}^{*}>Y_{i k}^{*}\right) \text { withk } \neq j(4)
$$

When we replace $Y_{i j}^{*}$ and $Y_{i k}^{*}$ in the equation above, we obtain the following equation:

$$
\operatorname{Prob}\left(\beta_{j} X_{i}+\epsilon_{i j}>\beta_{k} X_{i}+\epsilon_{i k}\right)=\operatorname{Prob}\left(\beta_{j} X_{i}-\beta_{k} X_{i}>\epsilon_{i k}-\epsilon_{i j}\right) \text { withk } \neq j(5)
$$

Due to the fact that the equation of participation is a function of the error term distribution, we assume that it is normally distributed with the variance equals to 1 . This leads to the Standard Probit Model (SPM) with the structural model of the probability for an individual $i$ to make a decision to participate to the labour force as a wage earned or as a self-employed giving by:

$$
\operatorname{Pr}\left(Y_{i}=1 \mid x_{i}\right)=\operatorname{Pr}\left(Y_{i}=Y_{i}^{*}>0 \mid x_{i}\right)=\int_{-\infty}^{\theta_{j} X_{i}} \frac{1}{\sqrt{2 \pi}} \exp (-0.5 t) d t(6)
$$

The maximum likelihood technic provides consistent and asymptotically normal estimators (Wooldridge, 2010; Long and Freese, 2001). Parameters obtained by computing marginal effects (dy / dx) for each 
working status inform on effects of the given characteristics on the probability to choose a working status. To take in account the potential problem of endogeneity related to the estimation of educational outcomes with cross section data, we will run a SPM without and with instrumental variables ${ }^{5}$ (IV). The use of IV supposes to find variables which are not correlated with the unobserved heterogeneity of individuals but with their educational levels. Due to the fact that there is not a general consensus about the choice of IV in the literature, some authors such as Kuepie et al. (2013), did not tackle the endogeneity issue of education due to the lack of relevant instruments and the difficulty to find relevant variables to use as instruments. Others authors often used data set information to choose IV. So, following authors as Totouom et al (2018), Kuépié et al. (2009), Ashenfelter and Zimmerman (1997), Lam and Schoeni (1995) or Blackburn and Neumark (1995) who used information's related to the family or individual context as instruments, we retain the educational level of the household head as instrument.

Because we suspect that unobservable factors that influence the decision to choose to participate to the labour force with a particular working status may be correlated to unobservable factors that affect young educational level used as a proxy of human capital accumulated, we assume that the educational level is endogenous. So, we run Extended Regression Models (ERM) notably a probit regression (PR) with endogenous covariate and a PR with ordinal treatment to test the robustness of results (See Wooldridge, 2014; Blundell and Powell, 2004).

Unfortunately, this study as many others faces several gaps related to the regularity, structure and content of surveys common to many SSA countries. If a dynamic analysis approach was appropriated for this study, the fact that data used provide from a cross-section survey limits its scope to a static analysis. In addition, compared to cohort or panel surveys, the Employment and Informal Sector Survey (EISS) which was supposed to be run every five years with the aim to provide a continuous assessment of the labour market situation, was ran only two times. Despite the fact that both surveys could allow a comparative analysis of the link between human capital accumulation and the occupational choice, information collected with the second EISS (EISSI 2) was more completed than the one obtained with the first EISS (EISS 1). For example, EISS 1 did not capture information about the educational level of the household head.

[3]

[4] Given the segmentation of the labour market in Cameroon, the Socio-professional classification of the National Institute of Statistics (2010) identifies three categories of workers: Self-employed, Wage earned and Unclassified workers which are all workers who are neither employees nor self-employed (family helpers, apprentices, etc.).

[5] Following the fact that instrumentation is based on sociodemographic characteristics or household information, instrumental variables capture various environmental influences. For this purpose, some authors use as instruments parental education, parental job, geographical proximity of a college or a 
place of residence, the presence of a sister in the family, household size (see Söderbom et al., 2006; Wooldridge, 2002; Ashenfelter and Zimmerman, 1997; Card, 1995; Butcher and Case, 1994; Garen, 1984).

\section{Data And Variable Descriptions}

Data used for this study provide from the second Employment and Informal Sector Survey (EISS 2) carried out by the National Institute of Statistics (NIS) in 2010. 8,160 households were surveyed with 34,500 respondents. The survey identified 14,625 workers made up of 7,322 self-employed $(6,845$ without employees and 477 with employees), 3,704 wage earned and 3,599 unclassified workers (family helpers, apprentices, etc.). In addition, the 18,742 individuals who represent the working age population (15 to 65 years old) are made up of 13,044 workers ( 69.60 per cent). Table 1 below which presents the working labour force distribution by socio-professional and age categorization reveals that 61.14 per cent of workers are individuals aged 15 to 35 years old (7,975 over 13,044 workers) with 29.30 per cent and 31.83 per cent respectively on $15-25$ and $26-35$ age categorization.

Table 1

Working labour force distribution by socio-professional and age categorization.

\begin{tabular}{|lllllll|}
\hline & $\mathbf{1 5 - 2 5}$ & $\mathbf{2 6 - 3 5}$ & $\mathbf{3 6 - 4 5}$ & $\mathbf{4 6 - 5 5}$ & $\mathbf{5 6 - 6 5}$ & Total \\
\hline Senior executive / management & 36 & 332 & 275 & 230 & 34 & 907 \\
\hline Skilled workers & 405 & 806 & 441 & 187 & 53 & 1,892 \\
\hline Unskilled workers & 354 & 321 & 127 & 46 & 16 & 864 \\
\hline Self-employed with employee (s) & 43 & 172 & 138 & 68 & 37 & 458 \\
\hline Self-employed without employee (s) & 1,192 & 2,077 & 1,487 & 1,009 & 604 & 6,369 \\
\hline Unclassified workers & 1,792 & 445 & 180 & 88 & 49 & 2,554 \\
\hline Total & 3,822 & 4,153 & 2,648 & 1,628 & 793 & 13,044 \\
\hline Source: Author with EISS data (National Institute of Statistics (NIS), 2010). & & \\
\hline
\end{tabular}

Graphic 1 below shows that 68.78 per cent of workers have an educational level of high school $(5,298$ over 13,044$)$ and numerous are individuals aged 15 to 25 years ( 35.15 per cent) and 26 to 35 years old (33.64 per cent).

\section{Variable Description And Summary Statistics}

If the United Nations Organization (UNO) defined a young person as any individual aged 15 to 24 years, it is relevant to underline that this definition used to vary from country to country (for example, it is 12 to 30 in Uganda, 15 to 34 in Ivory Coast and 18 to 35 years in Nigeria). Because there is not a consensus in the 
literature about this definition, our sample focuses on individuals aged 15 to 35 years as defined on the National Action Plan for Youth Employment (National Institute of Statistics, 2014) in order to take in account contextual realities common on comparable countries. Table 2 below describes variables selected for estimations.

Table 2

Summary description of variables selected for estimations.

\section{Educational Categorical variable used as the proxy of human capital individual had accumulated Level (EL) equals 3 if EL of University (ELU), 2 if EL of High School (ELHS), 1 if EL of Primary School (ELPS) and 0 if Unskilled.}

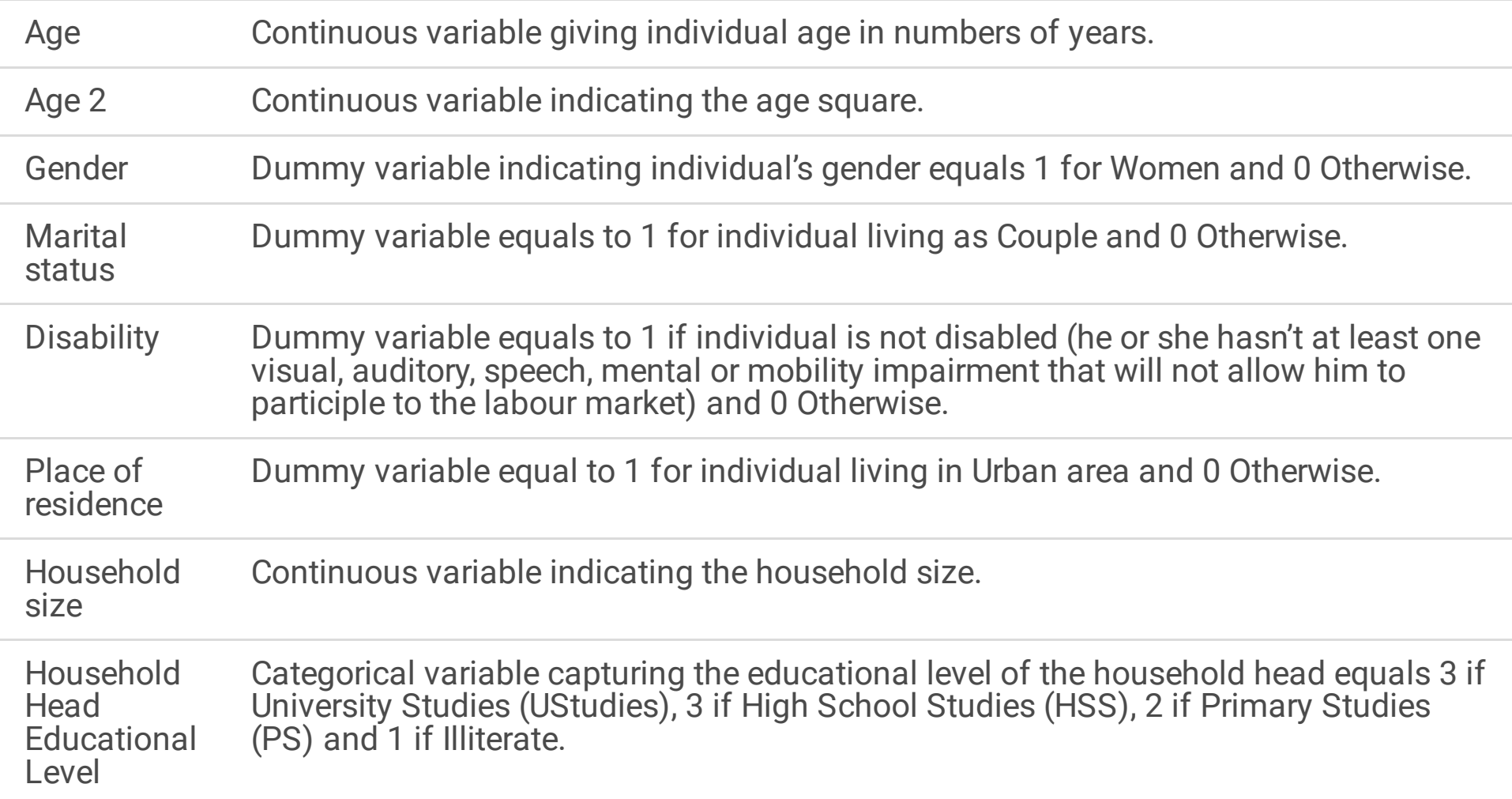

Source: Author with EISS data (National Institute of Statistics (NIS), 2010).

Table 3 below gives descriptive statistics related to variables described above. Concerning the variable of interest (individual educational level used as a proxy of human capital accumulated), data show that most young workers have an educational level of high school (46.27 per cent) and primary school (31.96 per cent). Data also reveal that 55.07 per cent of young workers leave in urban area and the educational level of household head used as instrument is concentrated in high school (38.37 per cent) and primary studies (33.84 per cent). 
Table 3

Summary descriptive statistics of variables.

\begin{tabular}{|c|c|c|c|c|c|}
\hline Variable & Observations & Mean & Std. Dev. & Min & Max \\
\hline \multicolumn{6}{|l|}{ 1. Dependent variables } \\
\hline Self-employed worker (SEW) & 7,891 & 0.4365733 & 0.4959922 & 0 & 1 \\
\hline Wage earning worker (WEW) & 7,891 & 0.2829806 & 0.4504756 & 0 & 1 \\
\hline \multicolumn{6}{|l|}{ 2. Explanatory variables } \\
\hline \multicolumn{6}{|l|}{ Individual characteristics } \\
\hline \multicolumn{6}{|c|}{ Main Variable of interest: Individual Educational Level (IEL) } \\
\hline Unskilled & 8,783 & 0.11320733 & 0.3385897 & 0 & 1 \\
\hline EL of Primary School Cycle (ELPS) & 8,783 & 0.3195947 & 0.4663461 & 0 & 1 \\
\hline EL of High School (ELHS) & 8,783 & 0.4627121 & 0.4986361 & 0 & 1 \\
\hline EL of University (ELU) & 8,783 & 0.0856199 & 0.279818 & 0 & 1 \\
\hline \multicolumn{6}{|l|}{ Others Variables } \\
\hline Age & 8,783 & 25.52283 & 5.723246 & 15 & 35 \\
\hline Age 2 & 8,783 & 684.1666 & 290.8096 & 225 & 1225 \\
\hline Women & 8,783 & 0.4833201 & 0.4997502 & 0 & 1 \\
\hline Couple & 8,783 & 0.4546283 & 0.4979655 & 0 & 1 \\
\hline Disabled & 8,783 & 0.9792782 & 0.1424597 & 0 & 1 \\
\hline \multicolumn{6}{|l|}{ Household characteristics } \\
\hline Urban area (Urban) & 8,783 & 0.550723 & 0.4974488 & 0 & 1 \\
\hline Household size (HSize) & 8,783 & 5.442559 & 3.649728 & 1 & 28 \\
\hline \multicolumn{6}{|c|}{ Instrument: Educational Level of the Household Head } \\
\hline Illiterate & 8,783 & 0.1740863 & 0.3792053 & 0 & 1 \\
\hline Primary Studies (PS) & 8,783 & 0.338381 & 0.4731858 & 0 & 1 \\
\hline High School Studies (HSS) & 8,783 & 0.3836958 & 0.4863129 & 0 & 1 \\
\hline University Studies (UStudies) & 8,783 & 0.103837 & 0.3050663 & 0 & 1 \\
\hline
\end{tabular}

\section{Empirical Results And Discussion}


Regarding the working labour force status in Cameroon, this section presents and discusses empirical findings of effects of young educational level used as a proxy of the human capital accumulated on the decision to participate to the labour force as a self-employed and as a wage earned. For that purpose, estimated coefficients are provided in Tables 6, 7, 8, 9, 10, 11 and 12 of Appendix and marginal effects (dy/dx) are reported in Tables 4 and 5 below for the working status enumerated above using SPM and ERM (Wooldridge, 2014; Blundell and Powell, 2004). Globally, econometric regressions reveal that young educational level has a significant effect on the odds to choose a particular working labour force status at the 1 per cent threshold. However, if the effect is positive for the decision to make a choice to work as a wage earned, it is negative for the one to work as a self-employed.

\section{Table 4: Effects of young educational level on the decision to participate to the working labour force as a wage earned (Wage earned = $1 \& 0=0$ therwise): Marginal effects (dy/dx).}


Binary Probit Model

$\begin{array}{lllll}\text { VARIABLES } & (\text { Model } 1) & (\text { Model } 2) & (\text { Model } 3) & (\text { Model } 4)\end{array}$

\begin{tabular}{|c|c|c|c|c|}
\hline \multirow[t]{2}{*}{ ELPS } & $0.0770213^{\star \star \star}$ & $0.0803198^{\star \star \star}$ & $0.0879363^{*}$ & 0.016996 \\
\hline & $(0.0139398)$ & $(0.0172418)$ & $(0.0315127)$ & $(0.0194097)$ \\
\hline \multirow[t]{2}{*}{ ELHS } & $0.1507958 * \star \star$ & $0.1228484^{\star \star \star}$ & $0.1284^{\star \star \star}$ & $0.0660461^{\star *}$ \\
\hline & $(0.0141439)$ & $(0.0183034)$ & $(0.0255444)$ & $(0.0213695)$ \\
\hline \multirow[t]{2}{*}{ ELU } & $0.3790391^{\star \star \star}$ & $0.281551^{\star \star \star}$ & $0.2626746^{\star \star \star}$ & $0.2813314^{\star \star \star}$ \\
\hline & $(0.0245881)$ & $(0.0314787)$ & $(0.0330768)$ & $(0.0456392)$ \\
\hline \multirow[t]{2}{*}{ Women } & $-0.1724288^{* * *}$ & $-0.1764772^{\star \star \star}$ & $-0.1764772^{\star \star *}$ & $-0.1736252^{\star * \star}$ \\
\hline & $(0.0086508)$ & $(0.0086505)$ & $(0.008631)$ & $(0.0088471)$ \\
\hline \multirow[t]{2}{*}{ Age } & $0.0765167 * \star \star *$ & 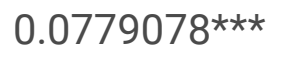 & $0.0779078 * \star \star$ & $0.0862822^{\star \star \star}$ \\
\hline & $(0.0073476)$ & $(0.0073305)$ & $(0.0073363)$ & $(0.0082977)$ \\
\hline \multirow[t]{2}{*}{ Age2 } & $-0.0012534 * * *$ & 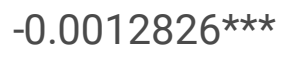 & $-0.0012826 * \star *$ & $-0.0014379 * * \star$ \\
\hline & $(0.000141)$ & $(0.0001407)$ & $(0.0001408)$ & $(0.0001565)$ \\
\hline \multirow[t]{2}{*}{ Couple } & $-0.0645473^{\star \star \star *}$ & $-0.06892 * \star \star *$ & 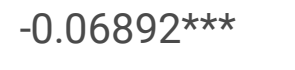 & 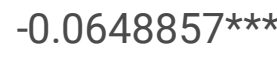 \\
\hline & $(0.0099804)$ & $(0.0100678)$ & $(0.0100551)$ & $(0.009949)$ \\
\hline \multirow[t]{2}{*}{ Disabled } & 0.0285263 & 0.0314689 & -0.0314689 & 0.0340483 \\
\hline & $(0.0319168)$ & $(0.0319898)$ & $(0.0319903)$ & $(0.0309264)$ \\
\hline \multirow[t]{2}{*}{ Urban } & $0.1749643^{\star \star \star}$ & $0.1674699 * \star \star \star$ & 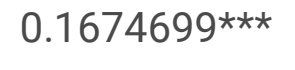 & $0.1509608^{* * *}$ \\
\hline & $(0.0092237)$ & $(0.0093129)$ & $(0.0094752)$ & $(0.0095535)$ \\
\hline \multirow[t]{2}{*}{ Hsize } & $-0.0036026 * \star \star *$ & -0.002661 & $-0.002661^{*}$ & -0.0021833 \\
\hline & $(0.0013712)$ & (0.0013729) & $(0.0013737)$ & $(0.0013791)$ \\
\hline
\end{tabular}

Instrument: Household Head Educational Level

\begin{tabular}{|c|c|c|c|}
\hline \multirow{2}{*}{ PS } & -0.0102979 & $-0.0102979 * * *$ & $-0.0332631^{* * *}$ \\
\hline & $(0.0163228)$ & $(0.0011906)$ & $(0.0015494)$ \\
\hline \multirow[t]{2}{*}{ HSS } & 0.0394924 & $0.0394924 * \star \star$ & $0.0713811^{\star \star \star}$ \\
\hline & $(0.0176092)$ & $(0.0012316)$ & $(0.0018653)$ \\
\hline UStudies & $0.1174364 * \star \star *$ & $0.1174364 * * \star$ & $0.1208644^{\star \star \star}$ \\
\hline
\end{tabular}




\section{Observations $\quad 7,891$}

7,891

7,891

7,891

Source: Author with EISS data (National Institute of Statistics (NIS), 2010).

Notes: (1) Models 1 and 2 are SPM without IV and SPM with IV, (2) Models 3 and 4 are ERM notably probit regression with endogenous covariate and probit regression with endogenous ordinal treatment. (3) Robust standard errors are in brackets. (4) ${ }^{* \star *}, * \star, *=$ Significant respectively at 1,5 and 10 per cent probability levels.

Concerning the odds associated to the decision to work as a wage earned, results obtained using the SPM without IV reveal that it increases with the rising of the educational level. Thus, compared to an unskilled, young person who have educational level of university are more inclined to make this choice than those with educational levels of high and primary school. For this purpose, if having an educational level of university increases the propensity for a young person to make a decision to participate to the working labour force as a wage earned by 0.379 point, it rises by 0.151 point and 0.077 point respectively for educational levels of high and primary school at the significance threshold of 1 per cent. The SPM with IV estimates the corresponding values at $0.283,0.123$ and 0.08 respectively for educational levels of university, high and primary school. The corresponding values obtained with the ERM have the same sign but the effect of educational level of primary school appears not significant (see Table 4 above). Despite this fact, the ERM result confirms the SPM result for educational levels of high school and university because its shows that a young person with the educational level of university is more disposed to become a wage earned than the one with an educational level of high school. Then, the PR with endogenous covariate establishes that having educational levels of high school and university increases the odds to make this choice respectively by 0.128 point and 0.263 point. The corresponding values provided by the PR with endogenous ordinal treatment are estimated at 0.066 point and 0.281 point.

But estimated coefficients obtained using the PR with endogenous covariate (see Table 9 of Appendix) show that the correlation between errors of both equations is significantly different from zero for two modalities (primary school and university). It means that the young educational level which measures the human capital he or she had accumulated is endogenous for these modalities and the sign of their correlation given by signs of corresponding estimated coefficients $(0.133$ and -0.109 respectively for primary school and university), allows us to conclude that unobservable factors which influence the probability for a young person to make a decision to participate to the labour force as a wage earned also affect the level of human capital accumulated in primary school and in university. So, we can assume that unobservable factors which decrease this probability increase the chance to have an educational level of primary school and decrease the odds to have an educational level of university.

Despite the fact that ERM did not validate the SPM results for the educational level of primary school, the particularity of these results, which support the predictions of the human capital theory (Becker, 1964) 
resides in the fact that young people with the educational level of university are more disposed to make this choice compared to those with high school educational level. These results corroborate the empirical analysis obtained by the National Institute of Statistics (INS, 2010) which reveals that most skilled young people seek wage earning jobs. Similar results have been obtained by Bocquier (1995) and Diagne (2006) in Senegal and Carmoe (2006) in Ivory Coast. These authors found that educational level is the main determinant of young person access to formal employment, particularly when their most-skilled. Similarly, Martinelli et al. (1999) showed that in France, well-educated young person's often have a better situation in the labour market after leaving the educational system.

\section{Table 5: Effects of young educational level on the decision to participate to the working labour force as a self-employed (Self-employed worker $=1 \& 0=$ Otherwise): Marginal effects (dy/dx)[6].}


Binary Probit Model

VARIABLES (Model 1) (Model 2) (Model 3)

\begin{tabular}{|c|c|c|c|}
\hline \multirow[t]{2}{*}{ ELPS } & 0.0273249 & 0.0247858 & 0.0239373 \\
\hline & $(0.0172409)$ & $(0.0207656)$ & $(0.0337002)$ \\
\hline \multirow[t]{2}{*}{ ELHS } & $-0.0629227 * \star \star$ & $-0.0620673^{\star}$ & -0.0603198 \\
\hline & $(0.0174252)$ & $(0.022217)$ & $(0.0279548)$ \\
\hline \multirow[t]{2}{*}{ ELU } & $-0.2969113^{* * *}$ & $-0.2571186 * \star \star$ & $-0.2719951^{\star \star \star}$ \\
\hline & $(0.0220351)$ & $(0.0300497)$ & $(0.0394928)$ \\
\hline \multirow[t]{2}{*}{ Women } & 0.0268328 & $0.0290247^{\star}$ & $0.0290247 *$ \\
\hline & $(0.0105789)$ & $(0.0106307)$ & $(0.0106184)$ \\
\hline \multirow[t]{2}{*}{ Age } & $0.1016712^{\star \star \star}$ & $0.1005647^{\star \star *}$ & $0.1005647 * \star \star$ \\
\hline & $(0.0085001)$ & $(0.0085048)$ & $(0.0085192)$ \\
\hline \multirow[t]{2}{*}{ Age2 } & $-0.001608^{* * *}$ & 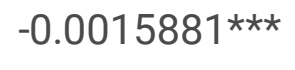 & -0.0015881 *** \\
\hline & $(0.0001645)$ & $(0.0001646)$ & $(0.0001648)$ \\
\hline \multirow[t]{2}{*}{ Couple } & $0.1141883 * \star * *$ & $0.1150827^{\star \star \star \star}$ & $0.1150827 * \star \star$ \\
\hline & $(0.0115507)$ & $(0.011634)$ & $(0.0116188)$ \\
\hline \multirow[t]{2}{*}{ Disabled } & -0.0347625 & -0.036223 & -0.036223 \\
\hline & $(0.0359703)$ & $(0.0359488)$ & $(0.0359482)$ \\
\hline \multirow[t]{2}{*}{ Urban } & $-0.0531545^{\star \star \star}$ & $-0.0507772^{\star \star \star}$ & $-0.0507772^{\star \star \star}$ \\
\hline & $(0.0112765)$ & $(0.0113974)$ & $(0.0114374)$ \\
\hline \multirow[t]{2}{*}{ Hsize } & $-0.0115198 * * *$ & $-0.0115678 * \star \star$ & $-0.0115679 * \star *$ \\
\hline & $(0.0015293)$ & $(0.0015425)$ & $(0.0015376)$ \\
\hline
\end{tabular}

Instrument: Household Head Educational Level

\begin{tabular}{lll} 
PS & 0.0071627 & $0.0071627^{\star \star *}$ \\
\hline & $(0.0183095)$ & $(0.000474)$ \\
\hline HSS & 0.0046773 & $0.0046773^{\star \star *}$ \\
\hline & $(0.0200976)$ & $(0.0005324)$ \\
\hline UStudies & -0.0673685 & $-0.0673685^{\star \star \star}$
\end{tabular}




\section{Observations $7,891 \quad 7,891 \quad 7,891$}

Source : Author with EISS data (National Institute of Statistics (NIS), 2010).

Notes: (1) Models 1, 2 and 3 are: SPM without IV, SPM with IV, Probit regression with endogenous covariate. (2) Robust standard errors are in brackets. (3) $* * *, * *, *=$ Significant at 1,5 and 10 per cent probability levels.

Concerning the decision to make a choice to work as a self-employed, results show that its odds decreases with the increasing of the educational level. Indeed, compared to an unskilled young person, having high school and university levels of education reduces this probability respectively by 0.063 point and 0.30 point with the SPB without IV. The corresponding values are respectively equal to 0.062 point and 0.26 point when using the model with IV. Thus, the fact that a young person with the level of education of university is more likely to give up this decision than the one with the one of high school supports the hypothesis that young people prefer wage earning jobs particularly when they are high skilled. Moreover, the fact that this result is significant at the 1 per cent threshold tends to support the hypothesis that this occupational choice is not a human capital outcome particular for skilled young people. This result is closed to the one obtained by Blanchflower (2000) who found in several OECD countries that the propensity to make this choice is higher among less educated than among high educated. However, it does not confirm neither the prediction of the human capital theory (Becker, 1964) nor empirical works which consider this occupational choice as a human capital outcome (Rees and Shah, 1986; Van Praag, 2005; Parker and Van Praag, 2006a). Indeed, the fact that skilled young people are more inclined to give up the decision to become self-employed allow us to argue that this occupational choice is probably a default option for young people in Cameroon particularly when they are high graduated. This conclusion raises questions about the quality of jobs in general and the future of work, which are common to most comparable SSA countries where the shortage of salaried jobs makes that self-employment became the primary source of job creation.

Taking into account the gender analysis, our regressions reveal that compared to a young man, being a woman increases the likelihood of becoming a self-employed and decreases the one of becoming a wage earned. This result is closed to one obtained by Carr (1996) in the USA who argued that women are more enable to choose self-employment because its flexibility generally allows them to conciliate family life and working life. It is also closed to Hakim's (1998) result which revealed that in Great Britain, while some women make this choice to escape gender patterns or discrimination in the labour market, others find a form of employment that offers flexibility. This result can also justify Kuepie et al. (2013) analysis who argued that employed women generally have less advantageous positions compared to men and this justify the fact that they are over-represented in the informal sector and in casual employment and earn less in the formal sector. 
[6] We didn't run marginal effects with the PR with Endogenous Ordinal Treatment because, the estimated coefficients provided in Table 10 of Appendix didn't reveal any endogeneity bias between young educational level and the probability to make a choice to work as a self-employed. This allows us to consider SPM results as robust.

\section{Conclusion And Recommendations}

This paper analyzes the effect of the educational level used as a proxy of the human capital accumulated on the decision to choose to participate to the working labour force in Cameroon. To achieve this objective, we uses discrete-choice models (Wooldridge, 2014; Brundell and Powell, 2004) on data draw from the second Employment and Informal Sector Survey (EISS 2) carried out by the National Institute of Statistics (NIS). Focusing on young person, econometric regressions show that the odds to make a decision to work as a wage earned increases when the educational level increase and the one to become a self-employed decreases when the educational level increases. If our results validate the prediction of the human capital theory (Becker, 964) for the decision to become a wage earned, its show that the level of education is an atypical determinant of the decision to choose to work as self-employed. Unfortunately, the fact that skilled young people are less inclined to make this choice and their propensity to give it up increases with the educational level reveals that this occupational choice is not a human capital outcome. Consequently, it is not appeared as an educational outcome but as a default option due to the shortage of wage earning jobs. Therefore, an in-depth analysis of the determinants of selfemployment choice can provide further information about reasons which motive establishment in this form of employment.

Then, when we take in account the structure of Cameroonian economy which is dominated by selfemployment activities and add to the government willingness to reinforce reforms adopted to improve transitions from school to employment, this labour market analysis allows us to suggest some economic policy recommendations which can be extended to comparable SSA countries. On one hand, the restructuration of the educational training system starting at least from high school cycle is required. This restructuration must focused on the development of the professional knowledges particularly in sectors with a high potential of self-employment and be followed by a setting-up of an apprenticeship plan compatible with labour market requirements. On another hand, based on the fact that labour market functioning in many of these countries encourages the development of self-employment activities, developing an awareness policy in order to provide information on the knowledge of job and professions related to self-employment from high school can help to improve their employability and prepare them for a more successful labour market insertion. Furthermore, this measure could also help to reduce the scope of the informal sector which the persistence is probably explained by the fact that individuals are not sufficiently inform in terms of job and professional knowledges which match with the training they choose.

\section{Declarations}




\section{Funding}

Author did not receive any funds or grants to support this study.

\section{Conflicts of interests / Competing interests}

Author has no conflicts of interest to disclose that are relevant to the content of this article.

\section{Availability of data and materials}

Author use data draw from the second Employment and Informal Sector Survey carried out by the National Institute of Statistics of Cameroon (NIS) in the National Territory (See Web link: http://www.statistics-cameroon.org for Data Repository Information). Despite the fact that it is not a public available due, it is possible to use a formal request by writing to the NIS Director.

Code Availability (Not applicable)

\section{Authors' contributions}

This manuscript has been written by KOUL NGWE MANGUELLE Maximilien. To finalize this manuscript, author received remarks and suggestions from Professors MONDJELI MWA NDJOKOU, ZAMO AKONO Christian and FOMBA KAMGA Benjamin, all Senior Lectures at the University of Yaoundé II.

\section{Ethics Approval and consent to participate}

The manuscript submitted for consideration as a PrePrint is an original article which is not published elsewhere and it is not currently under consideration for publication elsewhere.

\section{References}

Antoine, P., Razafindrakoto, M., \& Roubaud, F. (2001). Contraints de rester jeunes ? Evolution de l'insertion urbaine dans trois capitales africaines: Dakar, Yaoundé, Antananarivo. In Les jeunes, hantise de l'espace public dans les sociétés du Sud, Autrepart, 18, IRD-Editions / Editions de l'Aube.

Becker, G. S. (1964). Human Capital. University of Chicago Press, Third Edition

Blanchflower, D. (2000). Self-employment in OECD Countries. Labour Economics, 7, 471 -505.

Bocquier, P. (1995), L'insertion professionnelle des jeunes à Dakar. In La ville à guichets fermés? Itinéraires, réseaux et insertion urbaine, Séminaire IFAN-ORSTOM.

Bonnal, L., Fougère, D., \& Serandon, A. (1995). L'impact des dispositifs d'emploi sur les jeunes chômeurs : une évaluation économétrique sur données longitudinales. Economie et Prévision, 115, 1-28.

Bowles, S., \& Gintis, H. (1976). Schooling in Capitalist America. Basic Book, New York. 
Blundell, R. W., \& Powell, J. L. (2004). Endogeneity in semiparametric binary response models. Review of Economic Studies, 71, $655-679$

Carnoy, M., \& Levin, H. M. (1985). Schooling and Work in the Democratic State. Stanford University Press. Carr, D. (1996). Two Paths to Self-employment. Women and Men Self-employment in the United States. Work \& Occupations, 23, 26-53.

Diagne, A. (2006). L'insertion professionnelle des jeunes à Dakar : une tendance vers plus de précarité en début de vie active. Population Council (Dakar).

Drancourt, N. C., Roulleau-Berger, L. (1996). L'insertion des jeunes en France. Coll. Que Sais-Je ?, Presses Universitaires de France, Paris, $127 \mathrm{p}$.

Ekamena Ntsama, S. N., Abessolo, Y. A., \& Ngo Tadga, P. (2014), Genre et participation au marché du travail au Cameroun. International Journal of Innovation and Applied Studies, 7(3), 929-40.

Fang, C. (1993). Schooling as a job process. Economics Letters, 41, 85-91.

Fondeur, Y., \& Minni, C. (2006). L’accès des jeunes à l'emploi. Données sociales de la société française.

Germe, J. F., \& Marsden, D. (1991). Young people and entry paths to long term jobs in France and Great Britain, in Ryan P. (éd.). The Problem of Youth, Mac Millian, 179-199.

Giret, J. F. (2000). Pour une économie de l'insertion professionnelle des jeunes. CNRS Editions.

Groot, W., \& Oosterbeek, H. (1992). Optimal Investment in human capital under uncertainly. Economics of Education Review, 11, 41 - 49.

Hakim, C. (1998). Self-Employment in Britain: Recent Trends and Current Issues. Work, Employment and Society, 2, 421-450.

Hausman, J., McFadden, D. (1984). Specification Tests for the Multinomial Logit Model. Econometrica, 52(5), $1219-40$

National Institute of Statistics (NIS) (2015), Quatrième Enquête Auprès des Ménages : Premiers résultats, Institut National de la Statistique, Mai 2015, Cameroun.

National Institute of Statistics (NIS) (2014), Deuxième Enquête sur l'Emploi et le Secteur Informel. Phase 1 : Emploi. Rapport Principal, Ministère de l'Economie, de la Planification et de l'Aménagement du Territoire, Cameroun.

Kodde, D. A. (1986). Uncertainty and the demand for education. Review of Economics and Statistics, 68, $460-467$. 
Kuépié, M., Dzossa, A., \& Kelodjoué, S. (2013). Determinants of Labor Market Gender Inequalities in Cameroon, Senegal and Mali: The Role of Human Capital and the Fertility Burden. CEPS / INSTEAD, Working Papers No. 2013-08.

Kuépié, M., \& Nordman, C. T. (2013). Éducation et marchés du travail à Brazzaville et Pointe Noire (CongoBrazzaville). STATECO, No 107, 2013.

Lemelin, C. (1998). L'Economiste et l'Education. Presses de l'Université du Québec.

Long, S. J., \& Freese, J. (2001). Regression Models for Categorical Dependent Variables Using Stata. Stata Press, 4905 Lakeway Drive, College Station, Texas 77845

Martinelli, D., Simon-Zarga, G., \& Werquin, P. (1999). Génération 1992, profil, parcours et emplois en 1997. BREF, CEREQ, No 156.

Mayer, K. U., \& Konietzka, D. (1998). Formation professionnelle et débuts de carrière : crise ou stabilité du modèle allemand? Revue Française de Sociologie, 39, 269 - 296.

Meron M., \& Minni, C. (1995). Des études à l'emploi : plus tard et plus difficilement qu'il y a 20 ans. Economie et Statistique, 283-284, 9-31.

Miller, R. A. (1984). Job matching and occupational choice. Journal of Political Economy, 92, 1086-1120. Organization for Economic Cooperation and Development (1996), Employement Outlook, OEDC.

Parker, S. C., \& Praag Van, C. M. (2006a). Schooling, capital constraints and entrepreneurial performance: The endogenous triangle. Journal of Business \& Economic Statistics, 24, 416-431.

Pissarides, C. A. (1992). Loss of Skill during Unemployment and the Persistence of Employment Shocks. Quarterly Journal of Economics, 107, 1371-1391.

Praag Van, C. M. (2005). Successful Entrepreneurship: Confronting Economic Theory with Empirical Practice. Cheltenham, Edward Elgar.

Rees, H., \& Shah, A. (1986). An empirical analysis of self-employment in the UK. Journal of Applied Econometrics, 1, 95-108.

Schultz, T. W. (1961). Investment in human capital. American Economic Review, 51, 1-17.

Spence, M. (1974). Job Market Signaling. Quarterly Journal of Economy.

Tassaring, M. (1993). La dualité du système de formation professionnelle en Allemagne : Attraction et Perspective d'insertion. MittAB, 26, 131-161. 
Telles. (1993). Urban Labor Market Segmentation and Income in Brazil. Economic Development and Cultural Change, 231-249.

Totouom A., Mboutchouang, V.-D.-P., \& Kaffo Fotio, H. (2018). The Effects of Education on Labour Force Participation in Cameroon: A Gender Perspective. African Development Review, 30(1), 45-55.

Vernières, M. (1997). L'insertion professionnelle, analyse et débats. Economica, Paris, 197 p.

Vincens, J. (1998). L'insertion professionnelle des jeunes : quelques réflexions théoriques. FormationEmploi, 61, 59-72.

Vincens, J. (1999a). Sens et rôle de l'expérience professionnelle. In Béduwé (dir.), L'Expérience Professionnelle des Débutants. Cahier du LIRHE, 5, 17-34.

Vincens, J. (1999b). Parcours des étudiants et politiques universitaires. In Degenne (dir.), Cheminements de formation dans l'enseignement supérieur et parcours d'insertion professionnelle, Documents Séminaires du CEREQ, 141, 334-343.

Weiss, Y. (1972). The risk element in occupational and educational choices. Journal of Political Economy, 81, 1170-1188.

Wooldridge, J. M. (2014). Quasi-maximum likelihood estimation and testing for nonlinear models with endogenous explanatory variables. Journal of Econometrics, 182, 226 - 234.

Wooldridge, J. M. (2010). Econometric Analysis of Cross Section and Panel Data. MIT Press.

World Bank. (2019). World Development Indicator 2019, New York: World Bank.

\section{Graphic}

Graphic 1 is available in the Supplemental Files

\section{Figures}

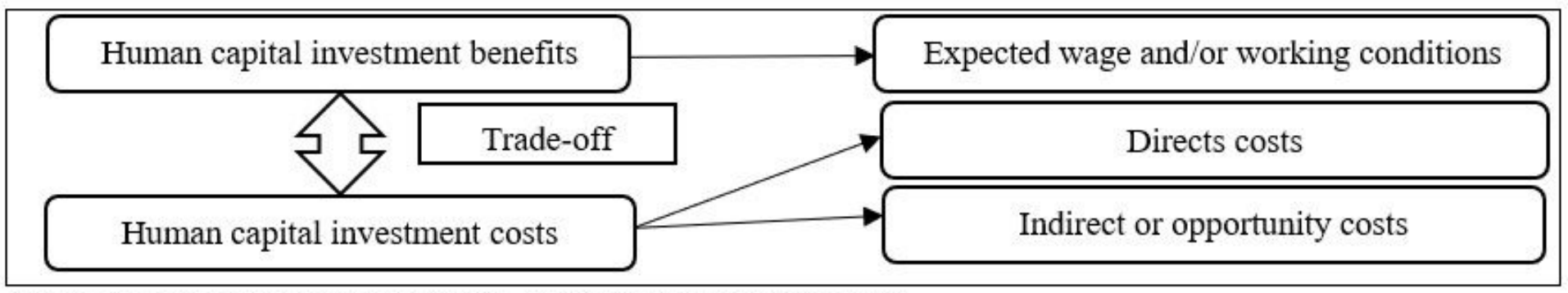

Source: Lesueur and Sabatier (2008), Microéconomie de l'emploi.

\section{Figure 1}


Illustration of a cost-benefit trade-off of human capital investment

\section{Supplementary Files}

This is a list of supplementary files associated with this preprint. Click to download.

- Graphic1.jpg

- Appendix.docx 